\title{
Adenoma pleomorfo gigante de glándula salivar menor. Extirpación a través de un abordaje transoral
}

\author{
Giant pleomorphic adenoma of minor salivary gland. Transoral resection \\ C. de Paula Vernetta, F.J. García Callejo, J.B. Ramírez Sabio, M.H. Orts Alborch, A. Morant Ventura, \\ J. Marco Algarra
}

Resumen: El adenoma pleomorfo es un tumor benigno de las glándulas salivares formado por la combinación de elementos epiteliales y mesenquimales. Generalmente constituyen el $60-70 \%$ de los tumores de la glándula parótida y el $40-60 \%$ de los de glándula submaxilar. Menos frecuentemente es su desarrollo a partir de una glándula salivar menor, presentándose como una masa intraoral dependiente de paladar o labio. Se expone el caso de un adenoma pleomorfo gigante de paladar duro y su exéresis por la vía transoral.

Palabras clave: Adenoma pleomorfo; Glándulas salivares menores; Paladar duro; Abordaje transoral.

Recibido: 22.05.2006

Aceptado: 16.06 .2008

\begin{abstract}
Pleomorphic adenoma is a benign tumor of the salivary glands that consists of a combination of epithelial and mesenchymal elements. The tumor most commonly arises from the parotid (6070\%) or submandibular glands. It develops less frequently on a minor salivary gland, presenting as an intraoral mass dependent on the palate or lip. A case is reported of giant pleomorphic adenoma resected using a transoral approach.
\end{abstract}

Key words: Pleomorphic adenoma; Minor salivary glands; Hard palate; Transoral surgery. 


\section{Caso clínico}

Paciente varón de 53 años y raza caucásica, sin antecedentes de interés que acude a puertas de Urgencias del Hospital por disfagia prolongada y sensación disneica de reciente evolución que se acentúa en decúbito supino. A la inspección se observa una masa que parece depender del paladar, indurada e indolora a la palpación, no friable y con una úlcera superficial en su cara ventral (Fig. 1). La masa comprime la lengua contra el suelo de la boca dificultando la movilidad de ésta. No se palpan adenopatías de tamaño significativo. No existe afectación de pares craneales bajos (IX, X, XI y XII). La sensibilidad facial está conservada. En la nasofibroscopia se aprecia una globulosa tumoración que ocupa la mayor parte de la naso y orofaringe, de predominio izquiedo y que con el decúbito supino contacta con la pared posterior faríngea dificultando la visualización de la luz glótica. El resto de la exploración ORL es normal. Las imágenes de la TC maxilofacial (Fig. 2) muestran una tumoración hipodensa de $10 \times 8,5 \times 5,6 \mathrm{~cm}$ que interesa cavidad oral, orofaringe y porción más inferior de cavum. La tumoración afecta por contiguidad a los músculos buccinador y pterigoideos, así como a la región gingival, paladar blando y región amigdalina. Existe a su vez erosión man-

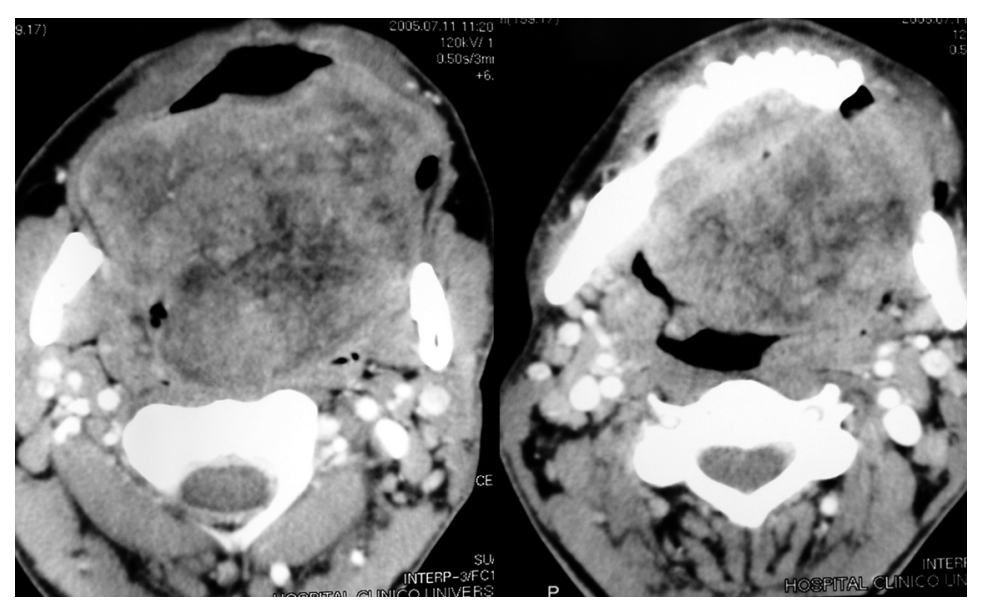

Figura 2. TC donde se observa el adenoma pleomorfo a distintos niveles de corte.

Figure 2. CT showing different slices of the pleomorphic adenoma.

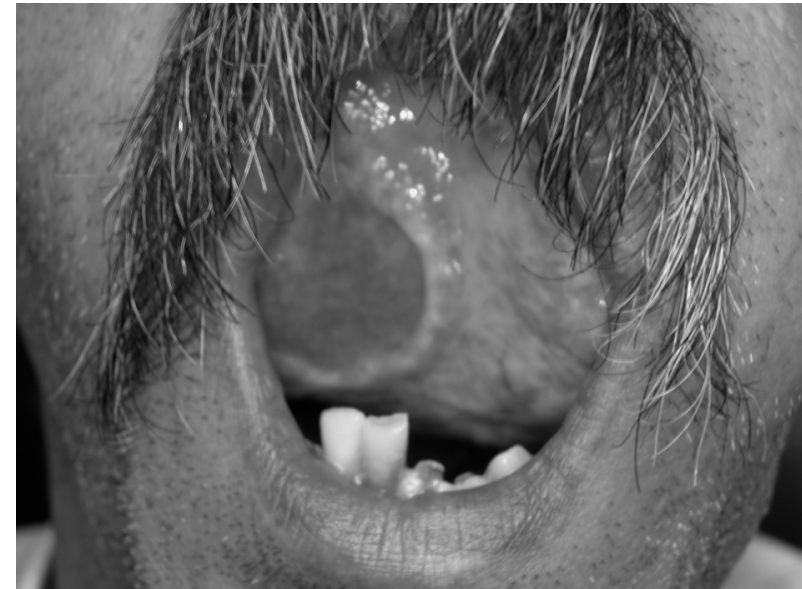

Figura 1. Imagen de la lesión. Se observa úlcera superficial por roce de la dentadura. La lengua queda comprimida contra el suelo de la boca.

Figure 1. Image of adenoma. Superficial ulcer due to rubbing against teeth is observed. The tongue is pressed against the floor of the mouth.

\section{Clinical case}

A 53-year-old Caucasian man without a medical history of interest came to the hospital emergency services for prolonged dysphagia and recent onset dyspnea that was more accentuated in supine position. On inspection, a mass apparently arising from the palate was observed. It was indurated, painless on palpation, nonfriable, and had superficial ulceration of the ventral surface (Fig. 1). The mass pressed the tongue against the floor of the mouth, which impaired its mobility. No enlarged lymph nodes of significant size were palpated. The lower cranial nerves (IX, X, XI, and $X I I)$ were not affected. Facial sensitivity was conserved. Nasofibroscopy revealed a globulous tumor that occupied most of the nasopharynx and oropharynx, particularly on the left side. In supine position, the tumor touched the posterior pharyngeal wall, impeding visude la cara posteroinferior del seno maxilar izquierdo. Adenopatías de tamaño no significativo en áreas I, II y III cervicales bilaterales. En la RM se evidencia la lesión hipointensa en T1 e hiperintensa en T2, dependiente de paladar que desplaza y comprime, distorsionando la morfología faríngea. La biopsia se informa como adenoma pleomorfo. La inmunohistoquimia es positiva para citoqueratina, proteína S100 y actina musculoespecífica. Se procede a la intubación del paciente por vía endonasal, para facilitar las maniobras quirúrgicas y por la imposibilidad de intubación bucal. Mediante un abordaje transoral, previa comprobación de la apertura bucal y a través de un abrebocas de Davis Boyle se lleva a cabo la exéresis total de la tumoración con márgenes de resección libres para tumor, de una tumoración pediculada en su parte superior dependiente de una glándula salivar menor de paladar duro (Figs. 3 y 4). El postoperatorio transcurre sin incidencias, estando al año el paciente asintomático y sin evidencia clínico-radiológica de lesión. alization of the glottal lumen. The rest of the ear, nose and throat examination was normal. Maxillofacial CT (Fig. 2) revealed a hypodense tumor measuring $10 \times 8.5 \times 5.6 \mathrm{~cm}$ that affected the oral cavity, oropharynx, and lowest part of the cavum. The tumor affected the buccinator and pterygoid muscles by contiguity, as well as the gingival region, soft palate, and tonsil area. Adjacent mandibular and maxillary erosion was present at the level of the posteroinferior aspect of the left maxillary sinus. Small bilateral lymph nodes were present in areas I, II, and III. MRI showed a lesion that was hypointense in $T 2$ and hyperintense in $T 2$ that moved with the palate, and compressed other structures, distorting pharyngeal morphology. The biopsy report was pleomorphic adenoma. The immunohistochemistry was positive for cytokeratin, 5100 protein, and muscle-specific actin. The patient was intubated nasally to facilitate surgical maneuvers because 


\section{Discusión}

Los tumores de glándulas salivares menores van a representar el $2-4 \%$ de los tumores de cabeza y cuello, el 10\% de los de cavidad oral y el 15-23\% de los tumores de glándulas salivares. ${ }^{1} \mathrm{La}$ localización más frecuente del adenoma pleomorfo de glándula salivar menor es el paladar duro, seguido de labio, mucosa bucal, suelo de boca, amígdala, faringe, área retromolar y cavidad nasal. ${ }^{2}$ No suelen presentar predisposición por sexos, pudiendo aparecer a cualquier edad, con el mismo comportamiento clínico. ${ }^{1}$ Se presentan habitualmente como una tumoración redondeada de crecimiento lento, indolora y firme a la palpación. Microscópicamente presenta células epiteliales y elementos mesenquimatosos, que a diferencia de los tumores de las glándulas mayores, tienden a ser más celulares y con menos componente mixoide o condroide, localizándose en la profundidad de la submucosa. Los tumores de glándulas salivares menores carecen de cápsula fibrótica (aunque poseen una cápsula muy fina) pudiendo dar una falsa apariencia de infiltración. A consecuencia de esto, su diagnóstico por imagen mediante TC y RM va a resultar esencial para evaluar con la mayor exactitud posible la extensión y las relaciones anatómicas del tumor en vistas a planear un adecuado abordaje quirúrgico. Tras el estudio del caso, se decidió su exéresis mediante un abor-

daje transoral. ${ }^{3}$ A pesar de los inconvenientes derivados (acceso limitado, difícil maniobrabilidad e intubación por vía nasal), a través de un abrebocas de Davis Boyle y previa comprobación de la buena función de ambas articulaciones témporomandibulares (Ortopantomografía) y de la aceptable movilidad cervical, se puede tener un acceso adecuado a este tipo de lesiones. Al igual que otros autores, 4,5 pensamos que ante la benignidad inicial del proceso es útil realizar técnicas quirúrgicas lo más conservadoras, siempre que la excisión sea posible. El pronóstico será excelente si la resección es adecuada. La radioterapia se reservará para las recidivas y casos inoperables. ${ }^{6}$ Se ha descrito la posibilidad de transformación maligna (2-9\%), generalmente a adenocarcinoma o carcinoma indiferenciado, aumentando el riesgo con la duración del tumor y con la edad media del paciente. ${ }^{7}$ Será necesario un seguimiento periódico por la posibilidad de recidiva local y malignización. Como conclusión diremos que actualmente consideramos el abordaje transoral como un acceso adecuado y suficiente para la exéresis correc-

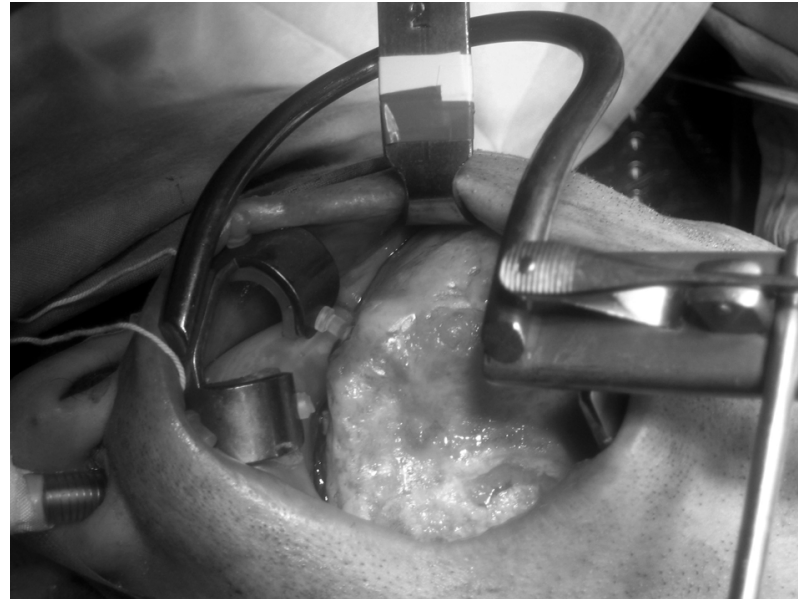

orotracheal intubation could not be performed. After verifying mouth opening, the tumor was completely resected with tumor-free resection margins via a transoral approach using a Davis Boyle bite opener. The tumor was pediculated and dependent on the upper part of a minor salivary gland of the hard palate (Figs. 3 and 4). The postoperative period passed without incident and one year after surgery the patient was asymptomatic and free of clinical and radiologic evidence of recurrence.

\section{Discussion}

Tumors of the minor salivary glands are responsible for 2 $4 \%$ of tumors of the head and neck, $10 \%$ of tumors of the oral cavity, and $15-23 \%$ of tumors of the salivary glands. ${ }^{1}$ The most frequent location of pleomorphic adenoma of a minor salivary gland is the hard palate, followed by the lips, oral mucosa, floor of the mouth, tonsil, pharynx, retromolar area, and nasal cavity. 2Pleomorphic adenomas do not usually present a sexual predisposition and they can appear at any age with the same clinical behavior. ${ }^{1}$ They are generally round, slow-growing tumors that are painless and firm in consistency. Microscopically, pleomorphic adenomas of the minor salivary glands consist of epithelial cells and mesenchymal elements that tend to be more cellular, with less myxoid or chondroid component, and located within the submucosa, in contrast with tumors of the major salivary glands. Tumors of the minor salivary glands do not have a fibrotic capsule (they have a very thin capsule) and they may have a false infiltrative appearance. One consequence of this is that CT and MRI imaging diagnosis will be necessary to evaluate as exactly as possible the extension and anatomic relations of the tumor in order to plan a suitable surgical approach. After studying the case, we decided to excise the tumor transorally. ${ }^{3}$ Despite the drawbacks of this approach (limited access, poor maneuverability, and need for nasal intubation), sufficient access can be obtained using a Davis Boyle bite opener after pre- 
ta de las tumoraciones benignas de paladar, previa comprobación de que no existan limitaciones anatómicas que contraindiquen dicha técnica.

\section{Bibliografía}

1. Sánchez Legaza $E$, y cols. Adenoma pleomorfo del paladar duro. ORL-DIPS 2005; 32:154-8.

2. Spiro RH, y cols. Salivary Neoplasms:overiew of a 35 year experience with 2807 patients. Head Neck Surgery 1986;8:177-84.

3. Gil-Carcedo LM. El acceso quirúrgico a los tumores de cavidad oral. Tumores de lengua móvil. Tumores de orofaringe. En: El Abordaje en el Tratamiento Quirúrgico de los Tumores de Cabeza y Cuello. Ponencia Oficial para 1992 de la SEORL y PCF 1992;243-56.

4. Moraitis $D, y$ cols. Pleomorphic adenoma causing acute airway obstruction. The J Laryngol Otol 2000;114:634-6.

5. García Arana L, y cols. Adenoma pleomorfo en espacio parafaríngeo. Extirpación a través de abordaje transoral. Rev Esp Cir Oral Maxilofac 2005;27:43-6.

6. Perez CA, y cols. Treatment of pleomorphic adenoma. Principles of practise of radiation oncology JB Lippincott company. Philadelphia 1987;521.

7. Feinmersser $\mathrm{R}, \mathrm{y}$ cols. Pleomorphic adenoma of the hard palate an invasive tumor? J Laryngol Otol 1983;97:1169-71.

8. Nardone M, y cols. Pleomorphic adenoma in inusual anatomic sites: case reports and review of literature. Acta Otorhinolaryngol Ital 2002;22:158-63.

9. Tucci $\mathrm{E}, \mathrm{y}$ cols. Enucleation of a pleomorphic adenoma of the palate. A conservative choice. Minerva Stomatol 2004;53:111-5. viously verifying the functionality of both temporomandibular joints (orthopantomography) and adequate cervical mobility. Like other authors, ${ }^{4,5}$ we think that, in light of the initial benignity of the process, the most conservative possible surgical technique is preferable whenever resection is possible. The prognosis will be excellent if resection is adequate. Irradiation is reserved for recurrences and inoperable cases. ${ }^{6}$ Malignant transformation has been reported (2-9\%), generally to adenocarcinoma or undifferentiated carcinoma. The risk of malignization increases with the duration of the tumor and mean age of the patient. ${ }^{7}$ Regular follow-up is required to detect local recurrence and malignization. We currently consider the transoral approach to be adequate and sufficient for correctly resecting benign tumors of the palate once it has been determined that there are no anatomic limitations that contraindicate the technique. 